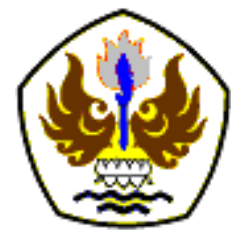

INFOMATEK

Volume 22 Nomor 1 Juni 2020

\title{
PENGARUH VARIASI ARUS LISTRIK PADA PENGELASAN FLASH BUTT WELDING TERHADAP KEKUATAN TARIK
}

\author{
Aa Santosa ${ }^{\star}$, Farradina Choria Suci, Rizal Hanifi \\ Jurusan Teknik Mesin \\ Universitas Singaperbangsa Karawang
}

\begin{abstract}
Abstrak: Penelitian ini bertujuan untuk mengetahui pengaruh variasi arus listrik pada pengelasan flash butt welding terhadap kekuatan tarik dan struktur mikro. Salah satu faktor yang mempengaruhi kekutan pada material adalah kekutan mekanik dari sifat material tersebut. jika material dilakukan pengelasan, maka dapat mempengaruhi kekutan tarik dan struktur material. penilitian ini menggunakan material baja AISI 1080 yang berdiameter $1.24 \mathrm{~mm}$ yang mengandung kadar $\mathrm{C}=0,083 \%, \mathrm{Si}=0,21 \%, \mathrm{Mn}=0,5 \%, \mathrm{P}=0,008 \%, \mathrm{~S}=0,007 \%, \mathrm{Cu}$ $=0,03 \%, \mathrm{Cr}=0,03 \%, \mathrm{Ni}=0,02 \%, \mathrm{~B}=0,013 \%$, Alt $=0,025 \%$, As $=0,06 \%, \mathrm{~N}=0.0038 \%$, dan $\mathrm{O}=0,1 \%$. Spesimen dilakuan pengelasan dengan variasi arus listrik dengan interval $25 \mathrm{~mA}$, mulai dari $700 \mathrm{~mA}, 725 \mathrm{~mA}$, $750 \mathrm{~mA}, 775 \mathrm{~mA}$, dan $800 \mathrm{~mA}$ dengan menggunakan metode penyambungan flash butt welding. Hasil tensile strength dari pengelasan flash butt welding dengan arus $700 \mathrm{~mA}$ sebesar $853.6 \mathrm{~N} / \mathrm{mm}^{2}$, pada arus $725 \mathrm{~mA}$ sebesar $867.7 \mathrm{~N} / \mathrm{mm}^{2}$, pada arus $750 \mathrm{~mA}$ sebesar $847.4 \mathrm{~N} / \mathrm{mm}^{2}$, pada arus $775 \mathrm{~mA}$ sebesar $881.8 \mathrm{~mA}$, dan pada arus 800mA sebesar $805.3 \mathrm{~mA}$.
\end{abstract}

Kata kunci: variasi arus listrik flash butt welding, baja AISI 1080, struktur mikro, tensile stenght

\section{PENDAHULUAN}

\subsection{Latar Belakang}

Pengontrolan arus pengelasan sangat mempengaruhi karakteristik hasil pengelasan karena pengontrolan ini mempengaruhi kualitas hasil las, seperti kekuatan geser, kekerasan dan kekuatan terhadap pengaruh dari luar. Pemilihan arus pengelasan akan mempengaruhi hasil las. Apabila arus pengelasan yang digunakan terlalu rendah, maka panas yang terjadi tidak cukup untuk

*) aa.santosa@ft.unsika.ac.id

Pertama diterima: 29 Mei 2020

Direvisi: 30 Mei 2020

Disetujui untuk publikasi: 30 Mei 2020 melelehkan material, sehingga menghasilkan daerah logam las yang kecil serta penembusan kurang dalam, sebaliknya bila arus pengelasan terlalu tinggi, maka pencairan logam induk terlalu cepat dan menghasilkan daerah logam las yang lebar serta penembusan yang dalam sehingga menghasilkan kekuatan tarik yang rendah dan menambah kerapuhan.Pada industri manufaktur wire drawing metode penyambungan flash butt welding sangat diperlukan guna menyambung wire yang akan dilakukan proses wire drawing. Penambahan panjang dari material sangat mempengaruhi hasil pada produk yang akan dilakukan proses selanjutnya, contohnya mengurangi produk 
yang terdapat banyak sambungan. Permasalahan yang terjadi Sering ditemukan hasil penyambungan yang berongga atau porositas di zona las, gosong, dan putus. Sehingga dalam Penelitian ini variasi arus listrik pada penyambungan flash butt welding perlu dilakukan pengujian tarik dan struktur mikro setiap ampernya (Fajar [1]).

Sehingga tujuan dari penelitian ini, Untuk mengetahui besar pengaruh variasi arus 700mA, 725mA, 750mA, 775mA dan $800 \mathrm{~mA}$ pengelasan pada metode penyambungan flash butt welding dengan menggunakan material jenis AISI 1080 yang berdiameter $1.24 \mathrm{~mm}$, serta Mengetahui kekuatan tarik dan struktur mikro terhadap material yang disambung dengan menggunakan flash butt welding.

\section{I.2 Flash Welding}

Flash welding merupakan penyambungan logam yang tidak menggunakan penambahan logam. Penyambungan Flash welding dengan memanfaatkan arus listrik yang di alirkan ke benda yang akan dilas dengan dilakukan penekanan sehingga terjadi loncatan listrik pada ujung benda yang disambung, yang mana akan menimbulkan panas dan mencairkan kedua ujung logam. Ketika kedua ujung logam menyatu dilakukan penahanan dengan tujuan memaksimalkan hasil sambungan (Prasetyo dkk. [2]), (Sugianto [3]).
Flash butt welding digunakan antara lain untuk menyambung baja strip pada proses rolling mill, menyambung kawat pada proses drawing, menyambung benda-benda berbentuk pipa, dan digunakan pada proses penyambungan rel kereta api.

\section{I.3 Masukan Panas Pada Daerah Las}

Panas yang di hasilkan akibat perbedaan resistansi listrik antara material yang di sambung atau dengan elektrodanya (Yakub [4]). Maka panas yang dihasilkan dapat dituliskan dengan persamaan :

$Q=I^{2} \cdot R \cdot t$

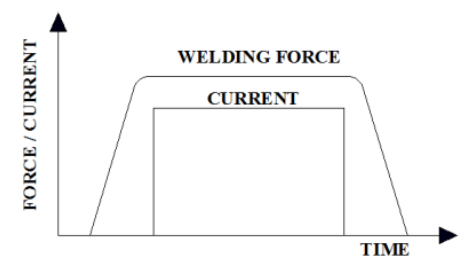

Gambar 1.

Siklus Penyambungan Flash Butt Welding

Ada beberapoa faktor yang mempengaruhi terhadap kekuatan las pada proses penyambungan flash butt welding, antara lain:

1. Pengaruh arus listrik

2. Pengaruh waktu penyambungan

3. Resistansi listrik

4. Gaya tekan elektroda

Panas yang timbul pada proses penyambungan berbanding lurus dengan besarnya tahanan listrik. Semakin besar resistansi pada logam, maka semakin besar panas yang diberikan sehingga logam cepat mencair. Tahanan ini dipengaruhi oleh jarak 
antara kedua elektroda dan luas penampang dari aliran (Syahrani dkk. [5]), (Tandika [6]).

$\mathrm{R}=\rho \cdot \frac{L}{A}$

\section{METODOLOGI}

\subsection{Diagram Alir Penelitian}

Penelitian ini dilakukan dengan beberapa tahapan yang dapat dilihat pada diagram alir di Gambar 2.

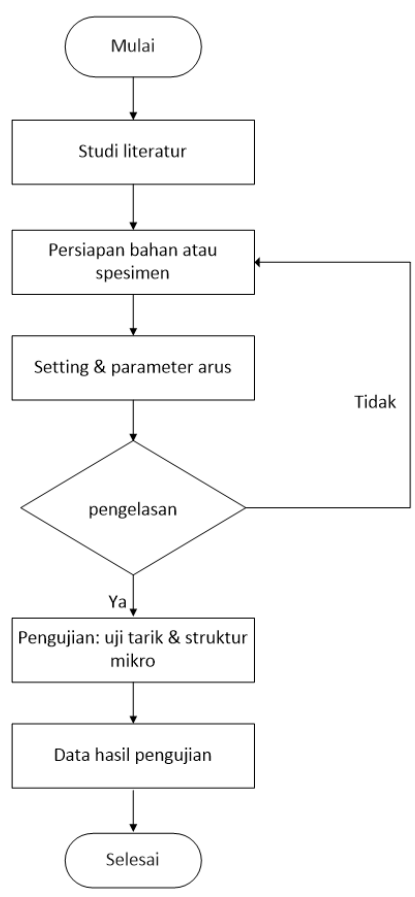

Gambar 2.

Diagram alir Penelitian

\subsection{Alat yang digunakan}

Alat yang digunakan dalam proses penyambungan flash butt welding, sebagai berikut.

1. Sarung Tangan, digunakan sebagai pelindung pada proses pemotongan kawat maupun pada proses penyambungan.
2. Cutting dalam penelitian ini cutting wire digunakan untuk memotong dan meratakan permukaan wire yang akan dilas.

3. Penggaris digunakan untuk mengukur spesimen yang akan dipotong sesuai kebutuhan.

4. Ampelas digunakan untuk membersihkan spesimen dari coting yang ada pada kawat sebelum dilakukan pengelasan.

5. Las listrik Penyambungan dengan menggunakan metode falsh butt welding karena sangat cocok untuk digunakan di aplikasikan pada proses wire drawing.

6. Mesin gerinda digunakan untuk meratakan dari hasil penyambungan pada proses penyambungan flash butt welding

\subsection{Pembuatan Spesimen Uji Tarik}

Pengujian tarik bertujuan untuk mengetahui sifat-sifat mekanik dan perubahanperubahannya dari suatu logam terhadap pembebanan tarik seperti tegangan, regangan, dan modulus elastisitas. Pengujian tarik merupakan jenis pengujian yang paling banyak dilakukan karena mampu memberikan informasi perilak mekanis material. Pengujian ini umumnya diperuntukan bagi pengujian beban-beban statik. Beban tarik tersebut dimulai dari nol dan berhenti pada beban atau tegangan patah tarik (Ultimate Strenght) dari logam yang bersangkutan.

$\sigma=\frac{\mathrm{F}}{\mathrm{A}}$

Sebelum dilakukan pengujian, spesimen dipotong sesuai kebutuhan kurang lebih +/- 
$50 \mathrm{~cm}$, agar bisa dilakukan pengujian uji tarik. Dan langkah-langkah nya sebagai berikut:

1. Spesimen yang digunakan adalah AISI 1080

2. Spesimen dipotong dengan ukuran $25 \mathrm{~cm}$ sebanyak 27 pcs, dan $60 \mathrm{~cm}$ sebanyak 3 pcs.

3. Setelah spesimen dipotong dilakukan pelurusan terhadap material dengan tujuan material ketika disambung dalam keadaan sejajar.

4. Ratakan permukaan kedua kawat yang akan disambung dan bersihkan couting pada bagian yang akan ditekan (clamp) menggunkan elektroda menggunakan ampelas dengan tujuan memaksimalkan arus listrik yang di alirkan pada proses penyambungan

5. Dilakukan penyambungan menggunakan metode penyambungan flash butt welding dengan variasi arus listrik yang digunakan antara lain $700 \mathrm{~mA}, 725 \mathrm{~mA}, 750 \mathrm{~mA}, 775 \mathrm{~mA}$, dan $800 \mathrm{~mA}$ yang dibuatkan sebanyak 5 sampel, dan 3 sampel tanpa dilakukan penyambungan.

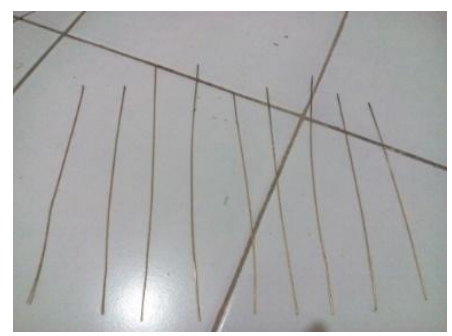

Gambar 3.

Spesimen sebelum pengelasan.

\section{ANALISIS DAN PEMBAHASAN}

\subsection{Proses Pengelasan Spesimen}

Langkah-langkah yang dilakukan dalam proses pengelasan adalah:

1. Mempersiapkan mesin las flash butt welding.

2. Mempersiapkan benda kerja yang akan dilas.

3. Pemilihan Grove yang ada pada elektroda dan harus sesuai dengan diameter kawat yang akan disambung, lihat pada gambar

4. Pemograman pada mesin las (diameter dan ampere ) yang akan dipakai dengan settingan $700 \mathrm{~mA}, 725 \mathrm{~mA}, 750 \mathrm{~mA}, 775 \mathrm{~mA}$, dan $800 \mathrm{~mA}$.

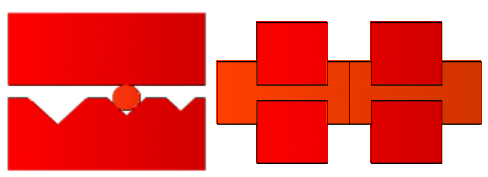

Gambar 4.

Penyesuaian Grove (a), dan pertemuan wire pada posisi tengah (b)

Setelah spesimen siap untuk dilakukan pengelasan dengan parameter arus $700 \mathrm{~mA}$, 725mA, 750mA, 775mA, dan $800 \mathrm{~mA}$, kemudian dilakukan pengujian terhadap spesimen tersebut dengan hasil sebagaimana terlihat pada Tabel 3.

Tabel 3.1 Hasil Pengujian

\begin{tabular}{ccccc}
\hline No & $\begin{array}{c}\text { Arus } \\
(\mathbf{A})\end{array}$ & $\begin{array}{c}\text { Breaking } \\
\text { Load }(\mathbf{N})\end{array}$ & $\begin{array}{c}\text { Elongation } \\
(\mathbf{m m})\end{array}$ & $\begin{array}{c}\text { Tensile } \\
\text { Strenght } \\
\left(\mathbf{N} / \mathbf{m m}^{2}\right)\end{array}$ \\
\hline 1 & 700 & 1029.2 & 3.57 & 853.6 \\
\hline 2 & 725 & 1040.1 & 2.51 & 867.7 \\
\hline 3 & 750 & 1084.6 & 2.69 & 847.4 \\
\hline 4 & 775 & 106.3 & 3.39 & 881.8 \\
\hline 5 & 800 & 964.2 & 2.36 & 805.3 \\
\hline
\end{tabular}




\subsection{Hubungan Arus Listrik Dengan Breaking Load}

Dari grafik pada Gambar 5, hubungan arus listrik dengan breaking load dapat diketahui bahwa terjadi peningkatan breaking load terhadap arus listrik $700 \mathrm{~mA}$ ke $725 \mathrm{~mA}$ dan 750mA namun mengalami penurunan breaking load terhadap arus listrik $775 \mathrm{~mA}$ dan $800 \mathrm{~mA}$ pada penyambungan dengan menggunkan metode penyambungan flash butt welding. Hal ini menunjukan bahwa variasi arus listrik terhadap penyambungan mempengaruhi terhadap nilai breaking load yang dihasilkan. Dari pengujian uji tarik ini nilai breaking load-nya paling tinggi terdapat pada arus $750 \mathrm{~mA}$ sebesar $(1084.6 \mathrm{~N})$, dan nilai breaking loadnya yang paling rendah terdapat pada arus $800 \mathrm{~mA}$ sebesar $(964.2 \mathrm{~N})$, dari beberapa arus listrik yang divariasikan.

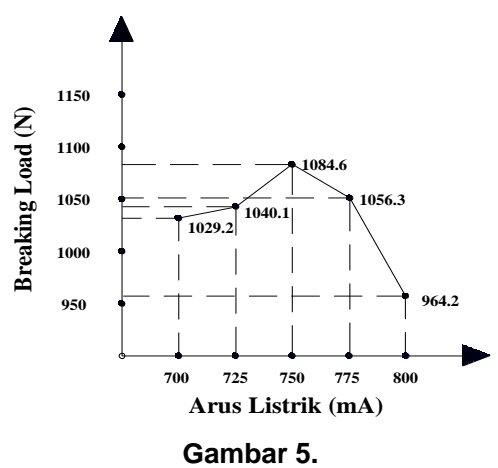

Grafik hubungan arus listrik dengan breaking load

\subsection{Hubungan Arus Listrik Dengan Tensile Strenght}

Dari grafik pada gambar 6 hubungan arus listrik dengan Tensile Strength, menunjukan bahwa terjadi kenaikan nilai tensile strength pada arus $700 \mathrm{~mA}$, ke $725 \mathrm{~mA}$ dan $775 \mathrm{~mA}$, dan terjadi penurunan Tensile Strength terhadap arus listrik $750 \mathrm{~mA}$, dan $800 \mathrm{~mA}$. Dari data tersebut dapat disimpulkan bahwa nilai tensile strength yang paling tinggi terdapat pada arus listrik $775 \mathrm{~mA}\left(881.8 \mathrm{~N} / \mathrm{mm}^{2}\right)$ dan nilai tensile strenght yang paling rendah terdapat pada arus listrik $800 \mathrm{~mA} \quad\left(805.3 \mathrm{~N} / \mathrm{mm}^{2}\right)$ dari beberapa arus listrik yang di variasikan.

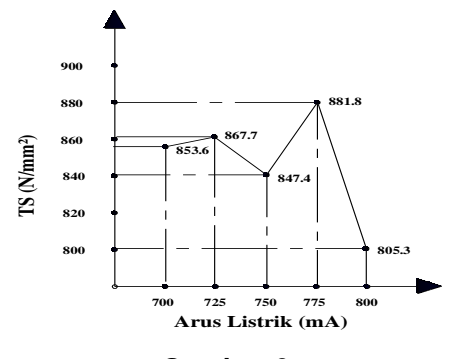

Gambar 6.

Grafik hubungan arus listrik dengan TS

\subsection{Hubungan Penambahan Panjang Dengan Breaking Load}

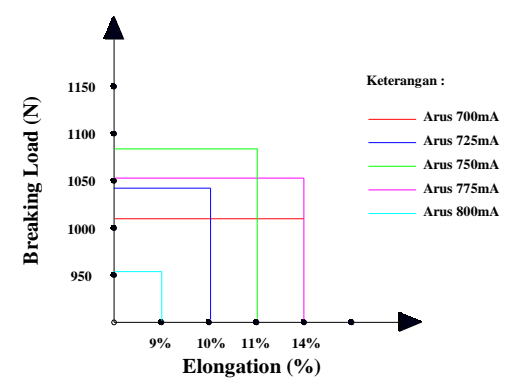

Gambar 7. Grafik hubungan Elongation dengan Breaking load

Dari hasil pengujian uji tarik yang dilakukan pada metode penyambungan flash butt welding, antara hubungan penambahan panjang(elongation) dengan breaking load 
tentang variasi arus listrik menunjukan bahwa arus listrik $700 \mathrm{~mA}, 725 \mathrm{~mA}, 750 \mathrm{~mA}$, dan $775 \mathrm{~mA}$ terjadi kenaikan breaking load maupun tensile strength nya dan terjadi penurunan nilai breaking load dan tensile strength nya pada arus listrik $800 \mathrm{~mA}$. Pada arus $700 \mathrm{~mA}$ dan $775 \mathrm{~mA}$ menghasilkan penambahan panjang paling tinggi diantara variasi arus listrik yang digunakan, yaitu (14\%) dan penambahan panjang yang paling rendah terdapat pada arus listrik $800 \mathrm{~mA}$ sebesar $(9 \%)$.

\section{IV.KESIMPULAN}

Dari hasil penelitian dan analisis yang dilakukan pada pengaruh variasi arus listrik pada pengelasan flash butt welding terhadap kekuatan tarik sebagai berikut:

1. Dari hasil pengujian uji tarik pada pengelasan dengan menggunakan metode penyambungan flash butt welding pada arus listrik $700 \mathrm{~mA}$ didapat nilai elongation sebesar 14\% dengan nilai TS 853.6 $\mathrm{N} / \mathrm{mm}^{2}$, arus listrik $725 \mathrm{~mA}$ sebesar $10 \%$ dengan nilai TS $867.7 \mathrm{~N} / \mathrm{mm}^{2}$, arus listrik $750 \mathrm{~mA}$ sebesar $11 \%$ dengan nilai TS 847.4 $\mathrm{N} / \mathrm{m}^{2}$ ), arus listrik $775 \mathrm{~mA}$ sebesar $14 \%$ dengan nilai TS $881.8 \mathrm{~N} / \mathrm{mm}^{2}$, dan pada arus listrik $800 \mathrm{~mA}$ sebesar $9 \%$ dengan nilai TS $805.3 \mathrm{~N} / \mathrm{mm}^{2}$.

2. Semakin tinggi elongation maka semakin ulet baja tersebut, semakin kecil elongation maka semakin tinggi keuletannya. untuk mendapatkan baja yang ulet dan tinggi nilai kekuatan tariknya sehingga menggunakan arus listrik $750 \mathrm{~m}$.

\section{DAFTAR PUSTAKA}

[1] Fajar, A.Z. Pengaruh kuat arus dan manik las pada pengelasan titik dua dan tiga tumpuk lembaran baja spcc. Skripsi Juli 2012.

[2] Prasetyo, B.D. dkk. Studi variasi pengelasan ulang terhadap cacat las dan kekerasan material aluminium 5083. Jurnal ITS.

[3] Sugianto, H. Pengaruh waktu gesek dan sidut chamfer tehadap hasil lasan alumunium 6061 pada proses friction welding. Skripsi 2016.

[4] Yakub, Y. Pengaruh arus listrik terhadap sifat mekanik mikro sambungan las baja tahan karat aisi 304. Jurnal Teknik Mesin. Desember 2013

[5] Syahrani, A. dkk. Variasi arus terhadap kekuatan tarik dan bending pada hasil pengelasan sm490. Jurnal Teknik Mesin. Juli 2013

[6] Tandika, A. Pengaruh variasi arus las terhadap sifat mekanik dan ketangguhan las smaw dengan elektroda nsn308. Skripsi 2015. 